\title{
The Impact of Quality Management Practices on Innovation in China: The Moderating Effects of Market Turbulence
}

\author{
Qunxiang Zhang1*, Xiaobin Feng'2, Xuan Xiang3 \\ ${ }^{1}$ School of Economics \& Management, Zhejiang Agriculture \& Forestry University, Lin'an, China \\ ${ }^{2}$ School of Economics \& Management, Zhejiang Sci-Tech University, Hangzhou, China \\ ${ }^{3}$ School of Management, Taizhou Vocational \& Technical College, Taizhou, China \\ Email: "swifttzhang@163.com,fengxb2002@163.com,419805680@qq.com
}

Received 1 March 2016; accepted 26 March 2016; published 29 March 2016

Copyright (C) 2016 by authors and Scientific Research Publishing Inc.

This work is licensed under the Creative Commons Attribution International License (CC BY). http://creativecommons.org/licenses/by/4.0/

(c) (i) Open Access

\begin{abstract}
Do quality management (QM) practices foster or hinder innovation? Attempts have been made to investigate this relationship, but the research has shown inconsistent results. Drawing on a review of related literature, this study proposes a theoretical model and a hypothesis in the Chinese context, with the aim of investigating the impact of QM practices on innovation performance. The investigation was made up of 383 questionnaires from nine Chinese provinces and cities. From here, this study further analyses the moderating effects of market turbulence on the relationship between QM practices and innovation performance. The results show that both QM infrastructure practices and core QM practices have a positive effect on innovation performance. Additionally, it is found that market turbulence positively moderates the relationship between the QM infrastructure practices and product innovation performance, but negatively moderates the relationship between core QM practices and process innovation performance. However, market turbulence does not moderate the relationship between infrastructure practices and process innovation performance; also, the moderating effects of core practices and product innovation performance are not significant.
\end{abstract}

\section{Keywords}

Quality Management Practices, Innovation Performance, Market Turbulence, China

\footnotetext{
"Corresponding author.
}

How to cite this paper: Zhang, Q.X., Feng, X.B. and Xiang, X. (2016) The Impact of Quality Management Practices on Innovation in China: The Moderating Effects of Market Turbulence. American Journal of Industrial and Business Management, 6, 291-304. http://dx.doi.org/10.4236/ajibm.2016.63027 


\section{Introduction}

In recent years, with the emergence of globalization, market competition, and the improvement in communication flows, quality management (QM) has become a crucial strategy for companies to maintain their market position [1]. At the same time, innovation has been widely used as a "winning order" criterion for companies to gain sustained competition. This study attempts to understand the relationship between QM and innovation, asking whether QM practices hinder the implementation of innovation. Although there has been much research into this area, the conclusions are still debated. For example, scholars such as Prajogo and Sohal (2001) have argued that companies that embrace QM practices will foster a fertile environment for innovation, facilitate knowledge sharing, and introduce positive organizational change [2]. Hence QM practices are viewed as a driver for organizational innovation. On the other hand, Slater and Narver (1994), among others, argue that QM practices hinder creativity [3], as they involve the enforcement of standards or formalization, which can grow into a "stickiness" regarding repeated or established procedures or processes; it is thus supposed that employees will be less likely to explore new way of changing. This is labeled as the "Nor Invented Here", or NIH syndrome [4]. However, the "NIH syndrome theory" is still in the conceptual stage and lacks empirical fieldwork or validity exercises. Hence, its claims are debatable. From there, this study aims to investigate the relationship between quality management and innovation in the Chinese context, with the objective of bridging the gap and clearing up confusions. 2. Theoretical Background and Hypothesis

\subsection{Quality Management and Innovation}

\subsubsection{Definitions}

QM practices refer to management strategies and plans that are essential in helping firms to improve quality, lower costs, and increase productivity [5]-[7]. Over the past few years, numerous QM frameworks have been developed [6], of which one of the most influential is that developed by Barbara B Flynn et al. (1995), which has been adopted by many for QM research [8]-[10]. Flynn’s QM practices (1995) consist of two key components of management practices_-namely, core QM practices and QM infrastructure practices. The former are expected to lead directly to improved quality performance, while the latter make up the environment that supports effective use of the core practices [6].

Similarly to QM practices, innovation is another competitive instrument that is essential for firms' survival and success. Given that innovation is a concept with rich connotations and dimensions, this study follows the path suggested by Read (2000) and Gopalakrishnan and Damanpour (1997) for understanding innovation namely, the "dual-core model" of innovation, which includes product and process innovation [11] [12]. The introduction of a new/improved product, generally referred to as product innovation, while a new/improved process to a particular industry, commonly referred to as process innovation [13] [14]. The hypothesis derived from this study is concerned with the relationship between QM practices and innovation.

\subsubsection{The Impact of QM Infrastructure Practices on Innovation}

According to Barbara B. Flynn et al. (1995), QM infrastructure practices are made up of 1) top management commitment, 2) employee involvement, and 3) customer focus [6].

Top management commitment: support for innovation from top management is embodied in three levelsnamely, tangible support, instrumental support, and social affection support [15]. Tangible support-which includes people, capital, laboratory equipment, and other inputs - arises when it is required during the innovation process. It is commonly acknowledged that top management commitment is crucial for injecting the necessary resources into the innovation process. Moreover, instrumental support is needed when employees formulate new ideas. Top management should thus put forward constructive feedback to ensure that the innovation process is on the right track, following a thorough evaluation. Even if there are criticisms, top management needs to play the role of advocate to protect employees' ideas. With respect to social affection support, according to social cognition theory [16], employees normally respond with positive psychological and emotional reactions when they perceive that they have emotional support from leaders. This will enhance their implicit motivation and desire for innovation; in turn, employees’ creativity capability will be improved.

Employee involvement: it is commonly accepted that employees play a major role in generating, fostering, and achieving innovation. Particularly when the innovation process is faced with high levels of uncertainty and changeability, employees need to become involved extensively. This is because involvement allows employees to be open minded, free to think, and with less worries of being blamed, thus encouraging new thinking and 
ideas to emerge. Furthermore, as organizational behavior theory outlines, employee involvement helps to improve working attitudes, to enhance the sense of identity toward innovation, to maintain positive emotions, to promote self-identification as a member of an innovative process, and others [17]-[19]. From there, employees' innovation psychology is likely to evolve "I am" to "I will", and then to "I can" [20]. Eventually, firms' innovation performance will be improved.

Customer focus: it is necessary that firms acquire innovative ideas from the market, or else identify new but unsatisfied customer needs. This can help firms to develop new products to satisfy customer needs, and to create value that results from innovation efforts for customers [21]. Hold that customer focus is a key driver for organizational innovation, and that the needs or requirements of the customer are valuable inputs that enable new products to be developed and innovated. In addition, María Leticia Santos-Vijande and Álvarez-González (2007) show that customer focus, through aggressive and proactive behavior, can also help firms develop new products and services and to respond to changing customer needs, which also brings benefits for product and process innovation [1].

To summarize, the following two hypotheses are proposed:

H1: QM infrastructure practices have a positive effect on fostering product innovation performance.

H2: QM infrastructure practices have a positive effect on fostering process innovation performance.

\subsubsection{The Impact of Core QM Practices on Innovation}

The core QM practices include 1) continuous improvement, 2) process flow management, and 3) supplier relationships [6].

Continuous improvement: Roffe (1999) has pointed out that continuous improvement (in innovation) promotes change and an innovative mindset, which are a key to the formation of the company's know-how [22]. Similarly, McAdam, Armstrong, and Kelly (1998) hold the view that a firm with a continuous improvement culture would be able to integrate with a culture of innovation, which has been shown to be positively related [23]. In the work undertaken by McAdam et al. (1998), the sampled firms that scored highly on innovation also scored highly on continuous improvement, and vice versa [23]. Additionally, Lorente, Dewhurst, and Dale (1999) discovered that learning that occurs in continuous improvement practices can enhance employees' awareness and knowledge of customers, competitors, and market, and these encourage individuals to come up with new and creative ideas, feedback, and so on [24]. Abrunhosa and Sá (2008) have claimed that continuous improvement requires an organizational culture that constantly encourages its members to innovate, minimizes their fear, and provides them with a rich and diverse set of tools [25].

Process flow management: as part of the TQM dimension, process management allows the firm to develop and document best practices [26], so that better know-how and a better learning base can be formed for identifying specific problems. A useful tool would be to document the process in a standard way (SOP), which may help improve productivity and performance [27]. Employees will then be able to spend more time on innovative problem solving, rather than performing non-value-adding activities. Furthermore, according to Nair (2006), firms following SOP should be able to establish shorter and more effective product development cycles, enabling the firm to respond to customer requirements in a timely fashion, thus mobilizing innovation [28]. More importantly, since different sets of SOP are derived from multiple processes, they can also help to enhance employees' skills in managing different processes-this, in turn, benefits the process innovation. Hence, in order for firms to carry out innovation activities, SOP is a good starting point, mainly because this management concept priorities the process flow and minimizes the non-value-adding activities, thus supporting product and process innovation [29].

Supplier relationships: suppliers, such as the extended firm or external parties [27], bring knowledge, information, and assets to the innovation process. Therefore, it is important to manage the relationship with suppliers in order to encourage their valuable input towards the performance of innovation [30]. Long-term collaboration and partnership with suppliers would build trust between the two parties, which in turn facilitates effective communications and fosters a transparent working relationship. Working together in such a trust-based environment, the two parties have no worries of calculated behavior or betrayal, and gain better communication and the possibility of knowledge transfer [31]. It is clear that the benefits also include learning and knowledge sharing for both parties, potential new knowledge, and creative proposals.

To summarize, another set of hypotheses is proposed, based on the discussions above:

H3: The core QM practices have a positive effect on fostering product innovation performance. 
H4: The core QM practices have a positive effect on fostering process innovation performance.

\subsection{The Impact of Contextual Variables on QM Practices and Innovation}

\subsubsection{Contextual Variable}

Contingency theory claims that the performance of a firm depends upon various internal and external variables [32] [33]. Such contextual variables, in QM practice, are dynamic in nature. The literature indicates that the contextual variables that affect the successful introduction of QM practices to a firm include organizational factors [34], managerial factors [33], external factors [35], and others. Given that firms exist in a certain environment, the external factors are regarded as critical moderating variables in organization theory and strategy management [26]. With the advent of globalization, networking, and fierce competition, customers' needs turn out to be increasingly diverse and uncertain, which in turn causes the market to show certain features of turbulence. Here, the term "turbulence" refers to changes that emerge without any predictability or fixed model. Given the importance of market turbulence as a critical indicator of the external environment, this study attempts to explore its moderating effect on the relationship between QM practices and innovation performance.

\subsubsection{The Moderating Effect of Market Turbulence on QM Infrastructure Practices and Innovation Performance}

In a turbulent market, customers' needs and preferences change frequently, as do the competitors, so that it becomes challenging for a production line to keep up with customer's changing needs [2]. To avoid this, positive measures are needed to make a more reliable prediction by analyzing customers' needs [1]. In such circumstances, top management commitment seems to be prominently important, because their commitment creates an environment of psychological security, thus minimizing employees' fears, and encourage them to be more adventurous and experimental in their work. Furthermore, tangible resources like people, capital, facilities, and social emotional support are needed for innovation in a turbulent market, while leaders' commitment and support is crucial for acquiring these necessary resources. Hence, in a market environment with high uncertainty, top management commitment is helpful for fostering product and process innovation.

Additionally, in turbulent markets, firms are likely to be confronted with various unstructured needs, so that the conventional method of market analysis and product development is difficult to sustain with the swift changes that occur. Therefore, the customer-focused approach seems appropriate and useful in monitoring, acquiring, and analyzing customers' needs [36]. With the assistance of rapid resource allocation (aggressive behavior) and continuous experiments (proactive behavior), this approach is likely to enable new products and new services to be developed in a tight window prior to changes in customers' needs [37], with the objective of creating value for customers. Likewise, a market with a high level of uncertainty will also present more uncertainty and changeability, which the innovation process needs to cope with [38]. However, the involvement of employees promotes their adaptability and initiative in such challenges. Market uncertainty is likely to be analyzed and predicted during paradigm shifts, so that organizational innovation performance is promoted. Also, in market environments with high uncertainty, attention should be paid to learning-oriented practices when QM practices are introduced; such a priority is claimed to benefit firms' innovation performance as well [2]. In summary, in turbulent market environments, there will be a greater impact on the performance of product and process innovation, exerted by leader commitment, customer focus, and employee involvement in the QM infrastructure practices.

On the other hand, under a stable market environment, customer needs and their preferences-along with technological development - change at a slower pace, so that competitors' behaviors can be relatively easily predicted, and firms' production lines can match customer needs. Furthermore, the existing methods or frameworks of QM practice are sufficient to handle the problems that firms encounter. As such, the impact of QM infrastructure practices on innovation, the commitment of leaders, customer focus, employee involvement, and others, are less obvious. For instance, customers' needs are easier to predict as firms adopt the customer-focus strategy, and so uncertainly decreases significantly in a mature or stable market environment. Likewise, because mature-market risk and uncertainty are reduced, the effects of leader commitment and support (especially for social emotional support) on innovation will be weakened. Based on the above analysis, following hypotheses are proposed:

H1a: The relationship between QM infrastructure practices and product innovation performance is moderated by market turbulence. The higher the level of market turbulence, the more significant the positive impact of QM 
infrastructure practices on product innovation performance.

H2b: The relationship between infrastructure practices and process innovation performance is moderated by market turbulence. The higher the level of market turbulence is, the more significant the negative impact of QM infrastructure practices on process innovation performance will be.

\subsubsection{The Moderating Effect of Market Turbulence on Core QM Practices and Innovation Performance}

When the market environment involves high uncertainty, customers' expectations and preferences change in a rapid manner. To be competitive, it is necessary that firms acquire customers' new needs. However, satisfying customers' changing needs with new products continuously being developed is very challenging, as "discontinuity innovation" does not work well with continuous improvement [3], which is based on the existing knowledge base. This may result in firms being in a disadvantageous position, failing to respond to the rapid changes of the external market environment [39]. Successful experience and models in prior processes of continuous improvement might also be hindered in a turbulent environment, so that the innovation performance of product and process would be affected. Similarly, in market environments characterized by high uncertainty, standardization-focused process management might decrease ambiguity (a crucial factor of innovation), making innovation more difficult [2]. This is because, by nature, repetitive routines refer to the documentation of SOPs, and repetition does not benefit firms at all in searching for and acquiring the changing needs of customer and new knowledge [40]. Consequently, product development and innovation will be affected in such turbulent market environments. Also, market environments with frequent changes increase the difficulty level and cost of maintaining a good supplier relationship. This is because cost pressure can negatively impact the trust between the two parties. Again, this would not help firms in terms of acquiring knowledge from suppliers-in particular, tacit knowledge, professional skills, or sensitive information that can only be shared in a mutual trusting working environment [31]. This would ultimately affect firms' innovation capacity and innovation performance. To summarize, it could be concluded that, in turbulent market environments, the positive impact of the core QM practices—including continuous improvement, process management, and supplier relationships—on product and process innovation performance will be significantly affected.

On the other hand, in market environments with low uncertainty, customers' preferences and technological development are relatively stable, so that what firms are faced with is structural need [29]. With respect to this type of demands firms are able to satisfy customers' needs through continuously improving their products and services so as to respond to the changes from the external market environment. Likewise, in a steady market environment, repetitive routines and SOPs built in process management are capable of supporting innovation activity, which promotes radical innovations of product and process [41]. Besides, the steady market environment is more favorable for established supplier relationships, which enables firms to acquire the technological resources and knowledge needed for innovation. Also, a trusted relationship would facilitate a more interactive and constructive dialogue between the two parties, and is also helpful in overcoming the "Not Invented Here" symptom [30]. Consequently, firms' innovation will be improved. This suggests that the moderating effect of a steady market environment will have a positive effect on the relationship between the core QM practices and the innovation performance of product and process. To summarize, the following hypotheses are proposed:

H3a: The relationship between core QM practices and product innovation performance is moderated by market turbulence. The lower the level of market turbulence, the more significant the positive impact of core QM practices on product innovation performance.

H4b: The relationship between core practices and process innovation performance is moderated by market turbulence. The lower the level of market turbulence, the more significant the positive impact of core QM practices on process innovation performance.

The conceptual model is formulated in Figure 1.

\section{Research Design}

\subsection{Sample and Data Collection}

Having taking cost, convenience, and geographic factors into account, the target sample for this study consisted 


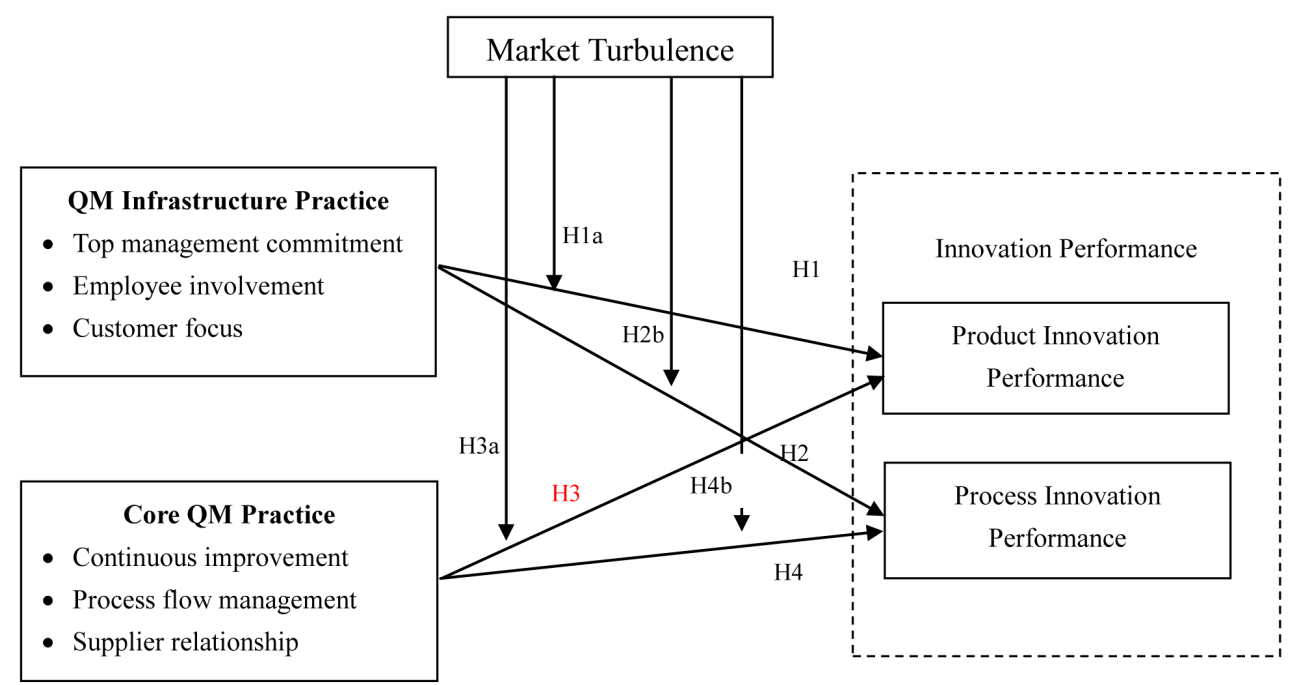

Figure 1. Research conceptual model.

of Chinese manufacturing firms from different provinces, with a focus on Zhejiang, where the local governments have heavily pushed the quality management initiative and awards. Questionnaire surveys were adopted for data collection, and were sent out to firms through various means, including e-mail and via personal contacts, from December 2011 to June 2012. Details of sampling are shown in Table 1. The primary industry surveyed was machinery manufacturing (34.42\%), followed by chemical industry (20\%), electronics and communication (13.49\%), and others.

The target respondents included general managers and top-to-middle managers with at least three years' working experience. The innovation performance section of the questionnaire required the input of top-to-middle managers, and the quality management practice part required answers from quality managers. By June 2012, 254 responses were obtained, of which 39 questionnaires were incomplete, giving a 56.14\% success rate.

\subsection{Measurement}

The design of questionnaire survey was carried out rigorously, beginning with an extensive literature review of QM practices, innovation, and others, with a focus on measurements. To suit the Chinese context, the study involved a series of questionnaire trials, in which three well-educated quality managers were invited to assess the logic between, and applicability of, the variables and measures. This was followed by inviting five top-to-middle managers to assess the clarity and comprehensibility of the questionnaire. The result was the identification of 15 items for measuring QM infrastructure practices, 12 core practice related items, 4 items each pertaining to product and process innovation, and 4 items relating to market turbulence. All questions are in the form of a Likert scale, with respondents choosing a number from 1 to 7 to determine their degree of agreement or disagreement with a statement [42].

QM practices: this study was in agreement with the work done by Barbara B Flynn et al. (1995) and by Prajogo and Sohal (2001) on QM constructs [2] [6]. We decided to use top management commitment, employee involvement, and customer focus as the three constructs for measuring core QM practices. On the other hand, continuous improvement, process flow management, and supplier relationship were employed to measure QM infrastructure practices.

Innovation performance: this variable was developed based on Martínez-Costa and Martínez-Lorente (2008) and Kim et al.'s (2012) research [41] [43], looking at the aspects of product and process innovation.

Market dynamics: this indicator was basically derived from the work of Hult et al. (2004) and of Maria Leticia Santos-Vijande and Alvarez-Gonzalez (2007) [21] [37]. Four indicators were thus adopted, including customer preference, market competition, and new customers' requirement. In this study, market turbulence variables were adopted from Hult et al. (2004) and Santos-Vijande et al.'s (2007) study [21] [37], and included rapidly changing buyer preference, wide-ranging needs and wants, and buyer entry and exit from the marketplace (market competition). 
Table 1. Sample firms’ characteristics.

\begin{tabular}{|c|c|c|}
\hline Characteristics & No. & Per cent \\
\hline \multicolumn{3}{|l|}{ Firm nature } \\
\hline State-owned enterprises (SOEs) & 41 & $19.07 \%$ \\
\hline Collective firms & 14 & $6.51 \%$ \\
\hline Private firms & 134 & $62.32 \%$ \\
\hline Foreign firms & 26 & $12.10 \%$ \\
\hline \multicolumn{3}{|l|}{ Firm size (no. of employees) } \\
\hline 100 and below & 36 & $16.74 \%$ \\
\hline $101-300$ & 63 & $29.30 \%$ \\
\hline $301-500$ & 72 & $33.48 \%$ \\
\hline $501-1000$ & 25 & $11.64 \%$ \\
\hline 1000 and above & 19 & $8.84 \%$ \\
\hline \multicolumn{3}{|l|}{ Firm age } \\
\hline 3 years and below & 23 & $10.70 \%$ \\
\hline 4 - 5 years & 45 & $20.93 \%$ \\
\hline $6-10$ years & 81 & $37.67 \%$ \\
\hline $11-20$ years & 49 & $22.79 \%$ \\
\hline 20 years and above & 17 & $7.91 \%$ \\
\hline \multicolumn{3}{|l|}{ Industries } \\
\hline Electronics and communication & 29 & $13.49 \%$ \\
\hline Machinery manufacturing & 74 & $34.42 \%$ \\
\hline Pharmaceutical & 17 & $7.91 \%$ \\
\hline Chemical and textile & 43 & $20.00 \%$ \\
\hline Innovative materials & 14 & $6.51 \%$ \\
\hline Metallurgy & 16 & $7.44 \%$ \\
\hline Others & 22 & $10.23 \%$ \\
\hline
\end{tabular}

\subsection{Reliability and Validity Test}

Overall, as shown in Table 2, scale reliability is high. All the items exceeded the usual recommendation of alpha $=0.70$ (Nunnally \& Bernstein, 1967) for establishing the internal consistency of the scale [44]. Moreover, content validity and construct validity were both considered in this study. Content validity refers to the adequacy with which a specific domain of content is reflected in the measurement items of an instrument [44]. It is subjectively judged by the researcher. Given the fact that all the identified items were derived from the prior literature, and went through a trial with professional, it therefore can be considered to have content validity. Construct validity measures the extent to which the items in a scale measure the same construct [44] [45]. Factor analysis was employed to evaluate the construct validity of each construct measure. The results in Table 2 show that item loading rage for each factor was relatively high. Thus, construct validity was demonstrated.

\subsection{Correlation Analysis}

This study employed SPSS 16.0 to analyze the descriptive statistics, correlations, and hierarchical regression. Table 3 reports the means, standards deviations, and coefficients of correlation for the variables. As Table 3 shows, the correlation coefficients for the measurements were highly related, ranging from 0.18 to 0.381 . This 
Table 2. Internal consistency analysis for all items.

\begin{tabular}{ccccc}
\hline Variables & Item members & No. of items & Items loading rage & Cronbach's $\alpha$ \\
\hline Top management commitment & TMC1-TMC5 & 5 & $0.651-0.752$ & 0.781 \\
Employee involvement & EI1-EI4 & 4 & $0.584-0.714$ & 0.783 \\
Customer focus & CF1-CF4 & 4 & $0.543-0.688$ & 0.752 \\
Continuous improvement & CI1-CI3 & 3 & $0.678-0.775$ & 0.852 \\
Process flow management & PFM1-PFM3 & 3 & $0.713-0.821$ & 0.821 \\
Supplier relationship & SR1-SR5 & 5 & $0.607-0.756$ & 0.785 \\
Product innovation performance & Prod1-Prod4 & 4 & $0.728-0.782$ & 0.871 \\
Process innovation performance & Proc1-Proc4 & 4 & $0.745-0.816$ & 0.902 \\
Market turbulence & MT1-MT4 & 4 & $0.768-0.826$ & 0.832 \\
\hline
\end{tabular}

Table 3. Correlations among the variables.

\begin{tabular}{ccccccc}
\hline Variables & Mean & St.d & 1 & 2 & 3 & 4 \\
\hline 1) QM infrastructure practices & 4.213 & 0.932 & 1 & & & \\
2) Core QM practices & 4.521 & 0.813 & $0.278^{* *}$ & 1 & & \\
3) Market turbulences & 4.081 & 0.678 & $0.233^{* *}$ & $-0.109^{*}$ & 1 & \\
4) Product innovation & 4.520 & 0.912 & $0.324^{* *}$ & $0.192^{*}$ & $0.205^{* *}$ & 1 \\
5) Process innovation & 4.453 & 0.834 & $0.381^{* *}$ & $0.183^{*}$ & $0.180^{*}$ & $0.349^{* *}$ \\
\hline
\end{tabular}

Note: $\mathrm{N}=215 ;{ }^{*} p<0.05$ level, ${ }^{* *} p<0.01$ level (two-tailed).

indicates that QM infrastructure practices and core practices had positive and significant relations to product and process innovation performance. One negative relationship was found: that between market turbulence and core practice $(\mathrm{r}=-0.109, \mathrm{p}<0.05)$.

\section{Regression Analyses}

Hierarchical regression was employed in this study to test the research hypotheses. For a start, the variation inflation factors (VIF) of each measurement were obtained; for QM infrastructure practices, core QM practices, and market turbulence, the VIF values are 1.241, 1.105, and 1.326 respectively-all of which are greater than 1. This finding indicates that the models are not affected by multicollinearity problems [46]. In order to assess and validate the independence of the error assumptions, Durbin-Watson statistics were adopted. The value is 1.916, which lies close to 2, indicating that no autocorrelation issues were found. Further, this study employs the following four procedures to test the hypothesis: Enter the control variables into the regression equation in step 1 (i.e., model 1), three predictors in step 2 (i.e., model 2), one moderate factor in step 3 (i.e., model 3); and two two-way interactions in step 4 (i.e., model 4). For each step, the coefficients $\mathrm{R}^{2}$ and $\Delta \mathrm{R}^{2}$ are evaluated.

\subsection{Result for Product Innovation Performance}

Table 4 shows the results of the regression analyses (models 1 to 4). Firstly, three control variables (size, nature, and age of firm) are entered into step 1 . This shows that these three control variables explained only 8.5 percent of the product innovation performance $\left(\mathrm{R}^{2}=0.085\right)$. Also, out of the three control variables, only the firm's age was found to have a significant impact on product innovation performance. All these findings show that the control variables have a weak influence on the dependent variable.

Secondly, two variables of quality practices-namely QM infrastructure practice and core QM practices - were entered into step 2 as two predictors. Model 2 showed that the additional variance explained was 14.5 percent $(p<0.01)$. It was also found that QM infrastructure practice and core QM practices had positive and significant mean effects on product innovation performance $(p<0.01)$. This finding supports the hypotheses H1 
Table 4. Result of hierarchical regression analysis (dependent variable: product innovation performance).

\begin{tabular}{|c|c|c|c|c|}
\hline Variables & Model 1 & Model 2 & Model 3 & Model 4 \\
\hline \multicolumn{5}{|l|}{ Control variables } \\
\hline Firm size & 0.023 & 0.032 & 0.027 & 0.044 \\
\hline Firm nature & 0.031 & 0.035 & 0.035 & 0.036 \\
\hline Firm age & $0.088^{*}$ & $0.101^{*}$ & 0.089 & 0.077 \\
\hline \multicolumn{5}{|l|}{ Independent variables } \\
\hline QM infrastructure practices (IP) & & $0.240^{* *}$ & $0.245^{* *}$ & $0.224^{* *}$ \\
\hline QM core practices $(\mathrm{CP})$ & & $0.127^{*}$ & $0.107^{*}$ & 0.092 \\
\hline \multicolumn{5}{|l|}{ Moderator variables } \\
\hline Market turbulence (MT) & & & $0.179^{* *}$ & $0.135^{*}$ \\
\hline \multicolumn{5}{|l|}{ Two-way interactions } \\
\hline MT*IP & & & & $0.224^{* *}$ \\
\hline $\mathrm{MT} * \mathrm{CP}$ & & & & -0.072 \\
\hline $\mathrm{R}^{2}$ & 0.085 & 0.230 & 0.468 & 0.547 \\
\hline Adjusted $\mathrm{R}^{2}$ & 0.073 & 0.214 & 0.436 & 0.525 \\
\hline$\Delta \mathrm{R}^{2}$ & & $0.145^{* *}$ & $0.383^{* *}$ & $0.462^{* *}$ \\
\hline
\end{tabular}

Note: Standardized regression coefficients are shown in the table; the values of $\Delta \mathrm{R}^{2}$ in models 2,3 , and 4 are compared against model $1 ;{ }^{*} p$ $<0.05,{ }^{* *} p<0.01$.

and H3. Thirdly, when the moderator factor (MT) is added into Model 2, the additional variance explained increased significantly to 46.8 percent of the explanations of variance in product innovation performance $\left(\Delta \mathrm{R}^{2}=\right.$ $0.383, p<0.01$ ). Lastly, as Table 4 shows, when the two-way interactions were entered, the increase in $\mathrm{R}^{2}$ from model 3 to model 4 was 0.46 , which is statistically significant $\left(\Delta \mathrm{R}^{2}=0.462, p<0.01\right)$. The results also showed that the coefficient for the two-way interaction effect of market turbulence and infrastructure practices was positive and significant $(b=0.224, p<0.01$ ), whilst market turbulence and core practices were negative and insignificant. Overall, the results suggest that the market turbulence factor positively moderates the impact of QM infrastructure practices on product innovation, but its moderating effect on the relationship between core QM practices and product innovation performance is not significant. Hence, H1a is justified, but H3a failed to be accepted.

\subsection{Result for Process Innovation Performance}

Following the above methods and steps of the data analysis, Table 5 reports the results of the regression analysis on process innovation performance conducted by QM practices, market turbulence, and the two-way interactions. Similarly, the results show that firm age is significant for process innovation performance, whilst the explanatory power of the other two control variables regarding process innovation performance is relatively low. Next, two QM practices are introduced to test the impact of the independent variable on the dependent variable when the other variables of the firms' characteristics are controlled for. The results show that Model 6 accounts for $23.4 \%$ of process innovation performance, and its explanatory power is higher than that of Model $5\left(\Delta \mathrm{R}^{2}=\right.$ $0.129, p<0.01)$. Regression analysis of Model 6 shows that QM infrastructure practices and core QM practices exert a positive and significant impact on process innovation performance $(p<0.05)$. Thus, hypotheses 2 and 4 are confirmed.

This is followed by introducing a moderating variable into the regression of Model 6. With market turbulence taken into consideration, the results show that Model 7 accounts for $41.7 \%$ of process innovation performance, with its explanatory power being further improved compared to model $6\left(\Delta \mathrm{R}^{2}=0.312, p<0.01\right)$. Additionally, with interaction variables added, Model 8 accounts for $52.4 \%$ of product innovation performance, with its explanatory power higher than that of Model 7. Regression analysis indicates that the interaction effect of QM infrastructure practices and market turbulence is not significant $(\mathrm{b}=0.087)$; the interaction effect of core QM 
Table 5. Result of hierarchical regression analysis (dependent variable: process innovation performance).

\begin{tabular}{ccccc}
\hline Variables & Model 5 & Model 6 & Model 7 & Model 8 \\
\hline Control variables & & & & \\
Firm size & 0.036 & 0.030 & 0.036 & 0.034 \\
Firm nature & 0.035 & 0.043 & 0.031 & 0.035 \\
Firm age & $0.124^{*}$ & $0.116^{*}$ & 0.094 & 0.102 \\
Independent variables & & & & $0.189^{* *}$ \\
QM infrastructure practices (IP) & & $0.211^{* *}$ & $0.194^{* *}$ & $0.116^{*}$ \\
QM core practices (CP) & & $0.141^{*}$ & $0.118^{*}$ & $0.293^{* *}$ \\
Moderator variables & & & $0.173^{* *}$ & \\
Market turbulence (MT) & & & & 0.087 \\
Two-way interactions & & & $0.121^{*}$ \\
MT*IP & & 0.234 & 0.417 & 0.524 \\
MT*CP & 0.105 & 0.218 & 0.392 & 0.508 \\
$\mathrm{R}^{2}$ & 0.078 & $0.129^{* *}$ & $0.312^{* *}$ & $0.419^{* *}$ \\
Corrected $\mathrm{R}^{2}$ & & & & \\
$\Delta \mathrm{R}^{2}$ & & & & \\
\hline
\end{tabular}

Note: Standardized regression coefficients are shown in the table; the values of $\Delta \mathrm{R}^{2}$ in models 6,7 , and 8 are compared against model $5 ;{ }^{*} p$ $<0.05,{ }^{* * *} p<0.01$.

practices and market turbulence achieved a significant level, with a native regression coefficient of interactions ( $b=-0.121, p<0.05$ ). The results show that the moderating effect of market turbulence on the relationship between infrastructure practices and process innovation performance is not significant, but that market turbulence could moderate the relationship between core practice and process innovation performance in a negative way. Thus, the implication is that hypothesis H2b fails to be accepted, while hypothesis H4b has been confirmed.

\section{Discussion and Conclusion}

This study has investigated the impact of QM practices on innovation performance in the Chinese context. It contributes to the quality management and innovation practice body of knowledge by identifying the moderating effects of market turbulence and the relationship between firm QM practices and innovation performance. The hypothesis was tested based on the empirical data from a sample of 383 firms across 9 Chinese provinces and cities, and the main conclusions drawn are as follows:

Firstly, it was found that, in the Chinese context, the local practices of quality management in the form of QM infrastructure practice and core QM practice had a significant positive effect on innovation performance [2] [41] [47]. This is in line with the findings of Prajogo and Sohal (2001), Choo, Linderman, and Schroeder (2007), and Kim et al. (2012), but inconsistent with the observations of Atuahene-Gima (1996), Slater and Narver (1994) on the negative relationship between the two [3] [48]. Given that QM infrastructure practices prioritize key practices, such as top management commitment, customer focus, and employee involvement, which would help to cultivate a pro-innovation working environment, innovations are thus more likely to occur. This is because, working under such condition, individuals are motivated and gain the desire to innovate their working methods [15]. This also enhances their recognition for innovation and mobilizes firms' innovation performance. Moreover, continuous improvement also encourages creative minds and learning, and is beneficial in that it allows repeated processes to gain opportunities for improvement on an incremental basis [38]. All of these will have effect on innovation performance [41].

Secondly, it has also been found that market turbulence has a positive moderating effect on QM infrastructure practice and product innovation performance (H1a). When the market environment involves high level of uncertainty, a mature level of QM infrastructure practice leads to a positive improved level of product innovation performance. This is because, in such a market environment where customer preference and demands change 
quickly, firms need to take the initiative to analyze customers' requirements and perform other market research, if they are to get ahead of their competition [2]. Driven by these factors, the creation of innovative products to meet customers' expectations is more likely. The implication is that, in dynamic and turbulent market conditions, factors such as top management commitment, customer focus, and employee involvement would be extremely impactful on product innovation. These QM practices are not only useful in identifying customer needs and committing resources to support innovation work, but such QM practices can also inspire employees to recognize the importance of innovation and to enhance their level of commitment to the innovative functions and roles, in order to eventually improve the firm's performance [2] [49]. This conclusion is again in line with the work undertaken by Maria Leticia Santos-Vijande and Alvarez-Gonzalez (2007), and Z. Li, Su, and Song (2008) on a similar finding [37] [50].

Further, this study also shows that market turbulence has a negative moderating effect on the relationship between the core QM practices and process innovation (H2b). In other words, in a stabilized market, the core QM practices had a significant positive impact on innovation performance; however, when market turbulence is high, the impact of the core QM practice on innovation performance will decrease. A possible explanation for this is that when the market is characterized by a high level of certainty, the customer requirements and product preferences are predictable, as is the relationship with competitors. Firms tend to focus more on cost reduction, minimization of variation in production, and productivity improvement [51]. Meanwhile, process management following SOP would be able to reinforce management capability and support innovation better [41]. Besides, through collaboration with suppliers to acquire the needed technology and knowledge, it is likely that innovation will improve through continuous improvement [29].

However, the results also reject the proposition regarding the positive moderating effect of market turbulence of QM infrastructure practices on process innovation performance. Possibly, this is because the high level of market turbulence demands radical technology development, and other radical changes; also, the firms will encounter various nonstructural demands. In order to cope with this, firms need to prioritize the product innovation strategy rather than that process innovation strategy with a limited amount of resources. Such a strategy can help firms to stay competitive and to respond quickly to customers' changing requirements. As such, the moderating effect on QM infrastructure practices and process innovation performance is not sensitive to firms, and can be neglected. In addition, it might also be affected by the small number of firms sampled, as well as the bias implicit in the chosen provinces in which the firms operate; this could also cause such a moderate factor to become insignificant.

This study also failed to prove the proposition regarding the positive moderating effect of market turbulence of the core QM practices on process innovation performance (H3a). This is probably because, in a relatively stable market, firms are reluctant to introduce new products as a result of product innovation, as firms focus more on dealing with structured demands, meaning that process innovation matters more. Accordingly, product innovation performance does not improve much under such circumstances. So, the core QM practices regarding process innovation performance are not associated with the nature of turbulent market.

Finally, this study has several limitations. First of all, although this study has taken diversification into account, it might be more meaningful if more industries were included in the sample, and if the sample size could be improved. Secondly, this study adopts cross-sectional data for examination, but the disadvantage is that an effort needs to be given to identify the causal relationship between the variables [52]. If longitudinal research is adopted in future studies, the results might be more reliable. Last, given that the focus of QM research lies in the impact of contextual factors on QM practices, this study investigates the moderating effect of one of the key external factors - market turbulence- yet it is also necessary to take into account other internal factors. It is suggested that more thorough future research is needed to explore the effect of a combination of a set of moderating factors, be they external factors or internal factors, on the relationship between QM practices and innovation performance.

\section{Acknowledgements}

The fund projects, 1) Zhejiang Province philosophy and Social Sciences planning project, "The research on agricultural products quality assurance model based on niche theory” No. 13NDJC035YB; 2) Zhejiang province major humanities and social science research program, "Research on the mechanism of agricultural product quality security based on the mutual symbiotic relationship between the leading enterprises and farmers-from 
the perspective of 1 niche theory” No. 2013QN081; 3) The major project of the National Social Science Fund, "The research on quality management models and methods for Chinese major equipment products", No. 12 \& ZD206; 4) Soft science research projects of Zhejiang province, "Small and medium-sized enterprise social responsibility behavior model, incentive measures and countermeasures, based on the empirical study of Zhejiang province”, No. 2015C35050.

\section{References}

[1] Santos-Vijande, M.L. and Álvarez-González, L.I. (2007) Innovativeness and Organizational Innovation in Total Quality Oriented Firms: The Moderating Role of Market Turbulence. Technovation, 27, 514-532. http://dx.doi.org/10.1016/j.technovation.2007.05.014

[2] Prajogo, D.I. and Sohal, A.S. (2001) Tqm and Innovation: A Literature Review and Research Framework. Technovation, 21, 539-558. http://dx.doi.org/10.1016/S0166-4972(00)00070-5

[3] Slater, S.F. and Narver, J.C. (1994) Does Competitive Environment Moderate the Market Orientation-Performance Relationship? Journal of Marketing, 58, 46-55. http://dx.doi.org/10.2307/1252250

[4] Woodman, R.W., Sawyer, J.E. and Griffin, R.W. (1993) Toward a Theory of Organizational Creativity. Academy of Management Review, 18, 293-321.

[5] Dahlgaard-Park, S.M. (2011) The Quality Movement: Where Are You Going? Total Quality Management \& Business Excellence, 22, 493-516. http://dx.doi.org/10.1080/14783363.2011.578481

[6] Flynn, B.B., Schroeder, R.G. and Sakakibara, S. (1995) The Impact of Quality Management Practices on Performance and Competitive Advantage. Decision Sciences, 26, 659-691. http://dx.doi.org/10.1111/j.1540-5915.1995.tb01445.x

[7] Van Der Wiele, T., Van Iwaarden, J., Williams, R. and Eldridge, S. (2011) A New Foundation for Quality Management in the Business Environment of the Twenty-First Century. Total Quality Management \& Business Excellence, 22, 587-598. http://dx.doi.org/10.1080/14783363.2011.568264

[8] Hendricks, K.B. and Singhal, V.R. (1997) Does Implementing an Effective TQM Program Actually Improve Operating Performance? Empirical Evidence from Firms that Have Won Quality Awards. Management Science, 43, 1258-1274. http://dx.doi.org/10.1287/mnsc.43.9.1258

[9] Kaynak, H. (2003) The Relationship between Total Quality Management Practices and Their Effects on Firm Performance. Journal of Operations Management, 21, 405-435. http://dx.doi.org/10.1016/S0272-6963(03)00004-4

[10] Reed, R., Lemak, D.J. and Mero, N.P. (2000) Total Quality Management and Sustainable Competitive Advantage. Journal of Quality Management, 5, 5-26. http://dx.doi.org/10.1016/S1084-8568(00)00010-9

[11] Read, A. (2000) Determinants of Successful Organisational Innovation: A Review of Current Research. Journal of Management Practice, 3, 95-119.

[12] Gopalakrishnan, S. and Damanpour, F. (1997) A Review of Innovation Research in Economics, Sociology And Technology Management. Omega, 25, 15-28. http://dx.doi.org/10.1016/S0305-0483(96)00043-6

[13] Drejer, I. (2004) Identifying Innovation in Surveys of Services: A Schumpeterian Perspective. Research Policy, 33, 551-562. http://dx.doi.org/10.1016/j.respol.2003.07.004

[14] Utterback, J.M. and Abernathy, W.J. (1975) A Dynamic Model of Process and Product Innovation. Omega, 3, $639-656$. http://dx.doi.org/10.1016/0305-0483(75)90068-7

[15] Amabile, T.M., Conti, R., Coon, H., Lazenby, J. and Herron, M. (1996) Assessing The Work Environment for Creativity. Academy of Management Journal, 39, 1154-1184. http://dx.doi.org/10.2307/256995

[16] Dweck, C.S. and Leggett, E.L. (1988) A Social-Cognitive Approach to Motivation and Personality. Psychological Review, 95, 256. http://dx.doi.org/10.1037/0033-295X.95.2.256

[17] Luthans, F. (2002) The Need for and Meaning of Positive Organizational Behavior. Journal of Organizational Behavior, 23, 695-706. http://dx.doi.org/10.1002/job.165

[18] Sila, I. (2007) Examining the Effects of Contextual Factors on TQM and Performance through the Lens of Organizational Theories: An Empirical Study. Journal of Operations Management, 25, 83-109. http://dx.doi.org/10.1016/j.jom.2006.02.003

[19] Wang, H., Tsui, A.S. and Xin, K.R. (2011) CEO Leadership Behaviors, Organizational Performance, and Employees’ Attitudes. The Leadership Quarterly, 22, 92-105. http://dx.doi.org/10.1016/j.leaqua.2010.12.009

[20] Yang, J.Z., Yang, D.T., Zhao, S.D., Jiang, L.D. and Qin, W.P. (2011) “I Am”, “I Can”, “I Will”-Employee Creativity Psychology and Employee Creativity Behavior. Science of Science and Management of S.\&T., 32, 165-172. (In Chinese)

[21] Hult, G.T.M., Hurley, R.F. and Knight, G.A. (2004) Innovativeness: Its Antecedents and Impact on Business Perfor- 
mance. Industrial Marketing Management, 33, 429-438. http://dx.doi.org/10.1016/j.indmarman.2003.08.015

[22] Roffe, I. (1999) Innovation and Creativity in Organizations: A Review of the Implications for Training and Development. Journal of European Industrial Training, 23, 224-241. http://dx.doi.org/10.1108/03090599910272103

[23] Mcadam, R., Armstrong, G. and Kelly, B. (1998) Investigation of the Relationship between Total Quality and Innovation: A Research Study Involving Small Organizations. European Journal of Innovation Management, 1, 139-147. http://dx.doi.org/10.1108/14601069810230216

[24] Lorente, A.R.M., Dewhurst, F. and Dale, B.G. (1999) TQW and Business Innovation. European Journal of Innovation Management, 2, 12-19. http://dx.doi.org/10.1108/14601069910248847

[25] Abrunhosa, A. and Sá, M.E. (2008) Are TQM Principles Supporting Innovation in the Portuguese Footwear Industry? Technovation, 28, 208-221. http://dx.doi.org/10.1016/j.technovation.2007.08.001

[26] Perdomo-Ortiz, J., González-Benito, J. and Galende, J. (2006) Total Quality Management as a Forerunner of Business Innovation Capability. Technovation, 26, 1170-1185. http://dx.doi.org/10.1016/j.technovation.2005.09.008

[27] Liker, J.K. (2004) The Toyota Way: 14 Management Principles from the World's Greatest Manufacturer. McGraw-Hill, New York.

[28] Nair, A. (2006) Meta-Analysis of the Relationship between Quality Management Practices and Firm PerformanceImplications for Quality Management Theory Development. Journal of Operations Management, 24, 948-975. http://dx.doi.org/10.1016/j.jom.2005.11.005

[29] Hoang, D.T., Igel, B. and Laosirihongthong, T. (2006) The Impact of Total Quality Management on Innovation: Findings from a Developing Country. International Journal of Quality \& Reliability Management, 23, 1092-1117. http://dx.doi.org/10.1108/02656710610704230

[30] Li, S. and Jiang, Y. (2011) The Correlation Mechanism between Supplier Involvement in NPD and The Enterprises’ Self-Determined Innovation Capability. Science Research Management, 32, 20-28. (In Chinese)

[31] Carson, S.J., Madhok, A., Varman, R. and John, G. (2003) Information Processing Moderators of the Effectiveness of Trust-Based Governance in Interfirm R\&D Collaboration. Organization Science, 14, 45-56. http://dx.doi.org/10.1287/orsc.14.1.45.12811

[32] Silvestro, R. (2001) Towards a Contingency Theory of TQM in Services-How Implementation Varies on the Basis of Volume and Variety. International Journal of Quality \& Reliability Management, 18, 254-288. http://dx.doi.org/10.1108/02656710110383520

[33] Sousa, R. and Voss, C.A. (2001) Quality Management: Universal or Context Dependent? Production and Operations Management, 10, 383-404. http://dx.doi.org/10.1111/j.1937-5956.2001.tb00083.x

[34] Zhang, D., Linderman, K. and Schroeder, R.G. (2012) The Moderating Role of Contextual Factors on Quality Management Practices. Journal of Operations Management, 30, 12-23. http://dx.doi.org/10.1016/j.jom.2011.05.001

[35] Flynn, B.B. and Saladin, B. (2006) Relevance of Baldrige Constructs in an International Context: A Study of National Culture. Journal of Operations Management, 24, 583-603. http://dx.doi.org/10.1016/j.jom.2005.09.002

[36] López-Mielgo, N., Montes-Peón, J.M. and Vázquez-Ordás, C.J. (2009) Are Quality and Innovation Management Conflicting Activities? Technovation, 29, 537-545. http://dx.doi.org/10.1016/j.technovation.2009.02.005

[37] Santos-Vijande, M.L. and Alvarez-Gonzalez, L.I. (2007) TQM and Firms Performance: An EFQM Excellence Model Research Based Survey. International Journal of Business Science and Applied Management, 2, 21-41.

[38] Scherer, F.M. and Harhoff, D. (2000) Technology Policy for a World of Skew-Distributed Outcomes. Research Policy, 29, 559-566. http://dx.doi.org/10.1016/S0048-7333(99)00089-X

[39] Terziovski, M. and Sohal, A.S. (2000) The Adoption of Continuous Improvement and Innovation Strategies in Australian Manufacturing Firms. Technovation, 20, 539-550. http://dx.doi.org/10.1016/S0166-4972(99)00173-X

[40] Klassen, R.D. and Menor, L.J. (2007) The Process Management Triangle: An Empirical Investigation of Process Trade-Offs. Journal of Operations Management, 25, 1015-1034. http://dx.doi.org/10.1016/j.jom.2006.10.004

[41] Kim, D.-Y., Kumar, V. and Kumar, U. (2012) Relationship between Quality Management Practices and Innovation. Journal of Operations Management, 30, 295-315. http://dx.doi.org/10.1016/j.jom.2012.02.003

[42] Bell, J. (2010) Doing Your Research Project. 5th Edition, Open University Press, Maidenhead.

[43] Martínez-Costa, M. and Martínez-Lorente, A.R. (2008) Does Quality Management Foster or Hinder Innovation? An Empirical Study of Spanish Companies. Total Quality Management, 19, 209-221. http://dx.doi.org/10.1080/14783360701600639

[44] Nunnally, J.C. and Bernstein, I.H. (1967) Psychometric Theory. 3rd Edition, McGraw-Hill, New York.

[45] Woon, K.C. (2000) Assessment of TQM Implementation: Benchmarking Singapore’s Productivity Leaders. Business Process Management Journal, 6, 314-330. http://dx.doi.org/10.1108/14637150010345497 
[46] Hair, J.F.J., Anderson, R.E., Tatham, R.L. and Black, W.C. (1995) Multivariate Data Analysis. Prentice Hall, Upper Saddle River.

[47] Choo, A.S., Linderman, K.W. and Schroeder, R.G. (2007) Method and Context Perspectives on Learning and Knowledge Creation in Quality Management. Journal of Operations Management, 25, 918-931. http://dx.doi.org/10.1016/j.jom.2006.08.002

[48] Atuahene-Gima, K. (1996) Market Orientation and Innovation. Journal of Business Research, 35, 93-103. http://dx.doi.org/10.1016/0148-2963(95)00051-8

[49] Chen, C.-J. and Huang, J.-W. (2009) Strategic Human Resource Practices and Innovation Performance-The Mediatingrole of Knowledge Management Capacity. Journal of Business Research, 62, 104-114. http://dx.doi.org/10.1016/j.jbusres.2007.11.016

[50] Li, Z., Su, Q. and Song, Y. (2008) Empirical Study on the Relationship between Quality Management Practice and Business Performance. Science Research Management, 29, 41-48. (In Chinese)

[51] Benner, M.J. and Tushman, M. (2002) Process Management and Technological Innovation: A Longitudinal Study of the Photography and Paint Industries. Administrative Science Quarterly, 47, 676-707. http://dx.doi.org/10.2307/3094913

[52] Chen, X., Xu, S. and Fang, J. (2008) Empirical Methods in Organization and Management Research. 2nd Edition, Peking University Press, Beijing. 